\title{
Tofieldia ulleungensis (Tofieldiaceae): A new species, endemic to Ulleungdo Island, Korea
}

\section{Hyeryun JO, Balkrishna GHIMIRE, Young-Ho HA, Kang-Hyup LEE and Dong Chan SON*}

Division of Forest Biodiversity and Herbarium, Korea National Arboretum, Pocheon 11186, Korea (Received 19 August 2020; Revised 5 September 2020; Accepted 18 September 2020)

\begin{abstract}
Tofieldia ulleungensis, a new species of the genus Tofieldia from the Nari Basin on Ulleungdo Island, Korea, is described and illustrated. The new species is similar to T. yoshiiana var. koreana in terms of the plant height and in that it has having a long raceme, whitish tepals, and whitish stigma, but can be readily distinguished from the latter by the presence of 1-2 linear cauline leaves, a slightly bent leaf apex, basal leaves which are twice as wide, a shorter pedicel, a revolute style, and crescent-shaped seeds.
\end{abstract}

Keywords: Tofieldiaceae, Tofieldia ulleungensis, endemic, Ulleungdo Island, Korea

The genus Tofieldia Huds. (Tofieldiaceae) comprised about 12 species distributed in the subarctic, temperate, and subtropical regions of the Northern Hemisphere (Chen and Tamura, 2000; Yamazaki, 2002; Tamura et al., 2004, 2010, 2011). The species are morphologically characterized by $2-$ ranked laterally flattened leaves, cupular bracteoles, raceme inflorescence (rarely a spike), actinomorphic flowers, 3 styles, and anther with two separate locules (Ohwi, 1965; Chen and Tamura, 2000). In Northeast Asia (northeastern China, Korea, Japan, and Far East Russia), seven taxa have been recognized as species level, which are mostly occurring in wetland areas of high mountains and less frequently in crevices of rocks or cliffs slopes (Chen and Tamura, 2000).

Tofieldia is currently included in the family Tofieldiaceae along with Isidrogalvia Ruiz \& Pav., Harperocallis McDaniel, Pleea Michx., and Triantha (Nuttall) Baker (Takhtajan, 1994, 1997; Marbberley, 2008). While the recognition of Tofieldiaceae and its placement in the Alistmatales are now generally accepted, the number of distinguishable genera and species within the family still remain unresolved (Thorne, 2000; Stevens, 2001; Marbberley 2008; Takhtajan, 2009; Tamura et al., 2010; Azuma and Tobe, 2011).

In Korea, Tofieldia fauriei H. Lév. \& Vaniot and T. taquetii H. Lév. \& Vaniot were the first species in this genus described from Jejudo Island by Léviellé (1908). They were subsequently recognized by Nakai (1911), but later he (Nakai, 1914) transferred T. taquetii to T. fauriei. In 1916, Nakai reported a new species, T. nutans Willd. ex Schult.f., from Rhobong, Pyeonganbuk-do, North Korea, and Chung (1957) recognized two species $T$. fauriei ( $=T$. taquetii) and $T$. nutans in Korean Flora. Lee (2006) mentioned three species $T$. coccinea Richardson (=T. nutans), T. fauriei, and T. nuda Maxim. in the Coloured Flora of Korea. However, Tamura et al. (2011) treated T. nuda as an endemic species to Japan. More recently, the Checklist of Korean Plants (Korea National Arboretum, 2017) listed three taxa $T$. coccinea var. coccinea, T. coccinea var. fauriei T. Yamaz. (=T. taquetii), and T. yoshiiana Makino var. koreana (Ohwi) M. N. Tamura with updated species names. In addition, size of the leaf, the curvature of leaf apex, presence or absence of projection on leaf margin, the shape of inflorescence and style, and length of the pedicel are considered being the key morphological characters for species delimitation in Tofieldia (Chen and Tamura, 2000; Tamura et al., 2010, 2011, 2013).

During recent field investigations conducted on the Ulleungdo Island of Korea, we found an unusual and rather isolated population of Tofieldia that appeared morphologically different from other known taxa of the genus in Korea. After careful examination of the various flora and herbarium specimens from Korea and adjacent countries as well as the

\footnotetext{
*Author for correspondence: sdclym@korea.kr
} 

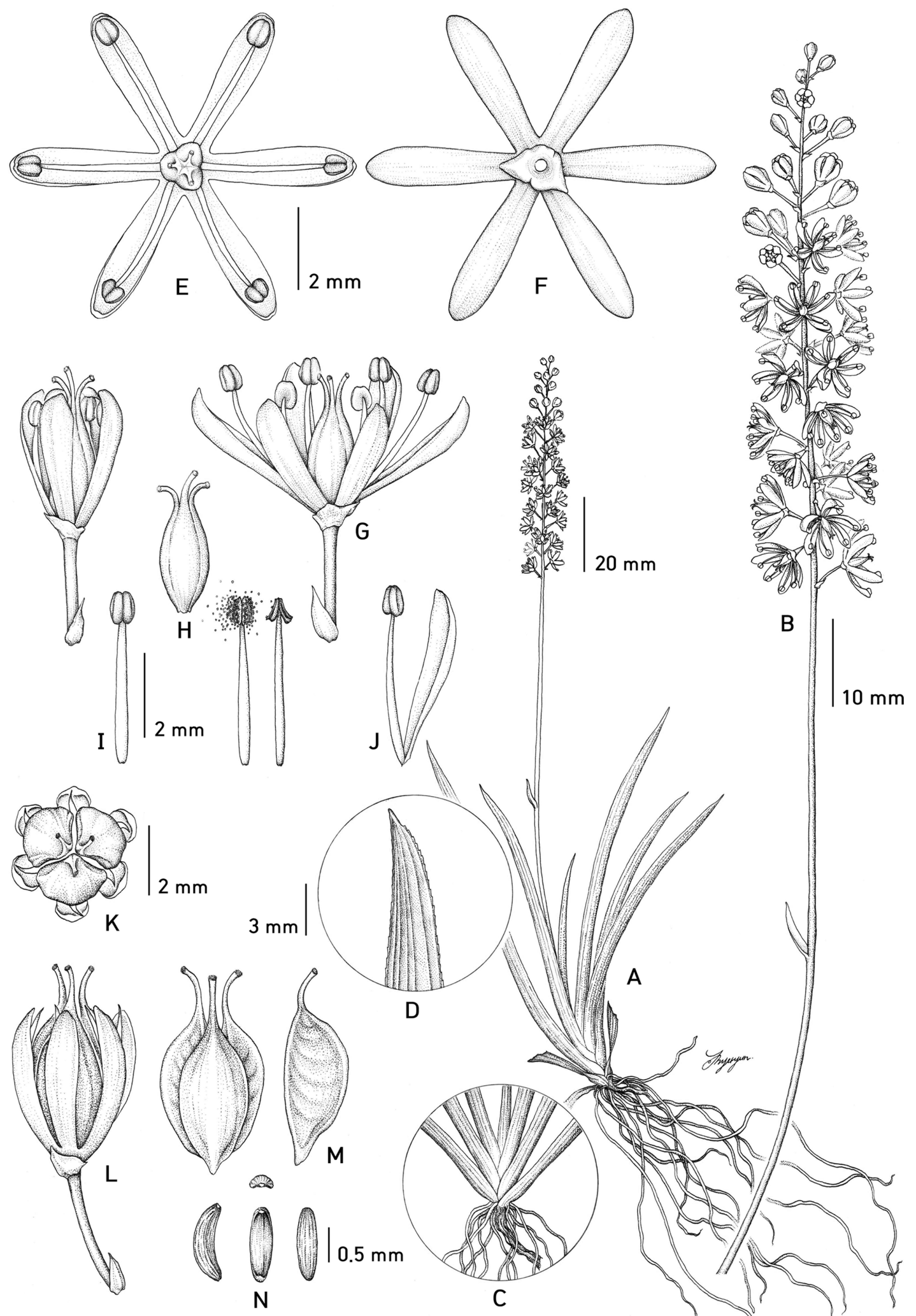

A

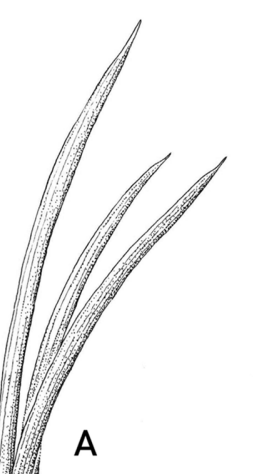

$10 \mathrm{~mm}$

Fig. 1. Tofieldia ulleungensis. A. Habit. B. Inflorescence. C. Two-ranked leaves. D. Leaf apex. E. Flower (top view). F. Flower (abaxial view). G. Flower (side view). H. Pistil with three styles. I. Stamen. J. Tepal and stamen. K. Fruit (top view). L. Fruit (side view). M. Capsule. N. Seeds. Illustrations by Hyeryun Jo. 


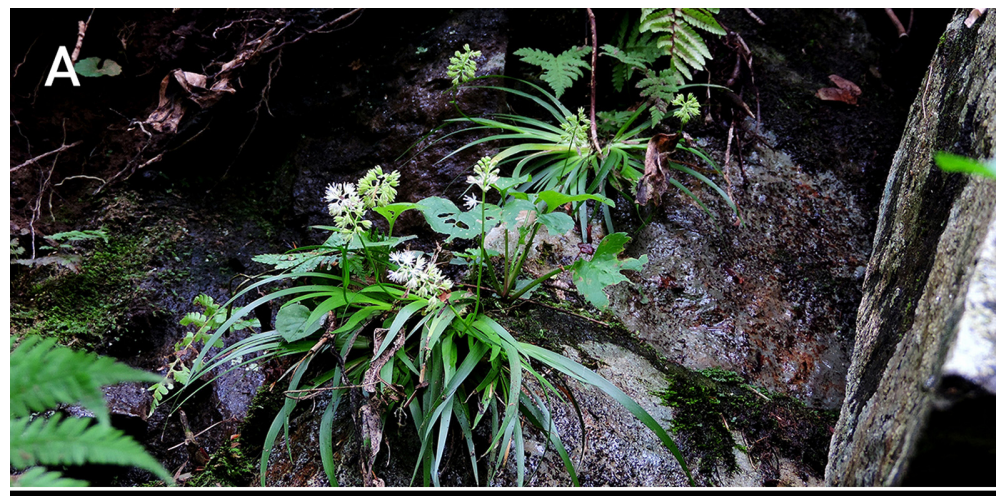

\section{C}

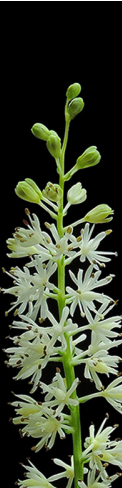

\section{B}
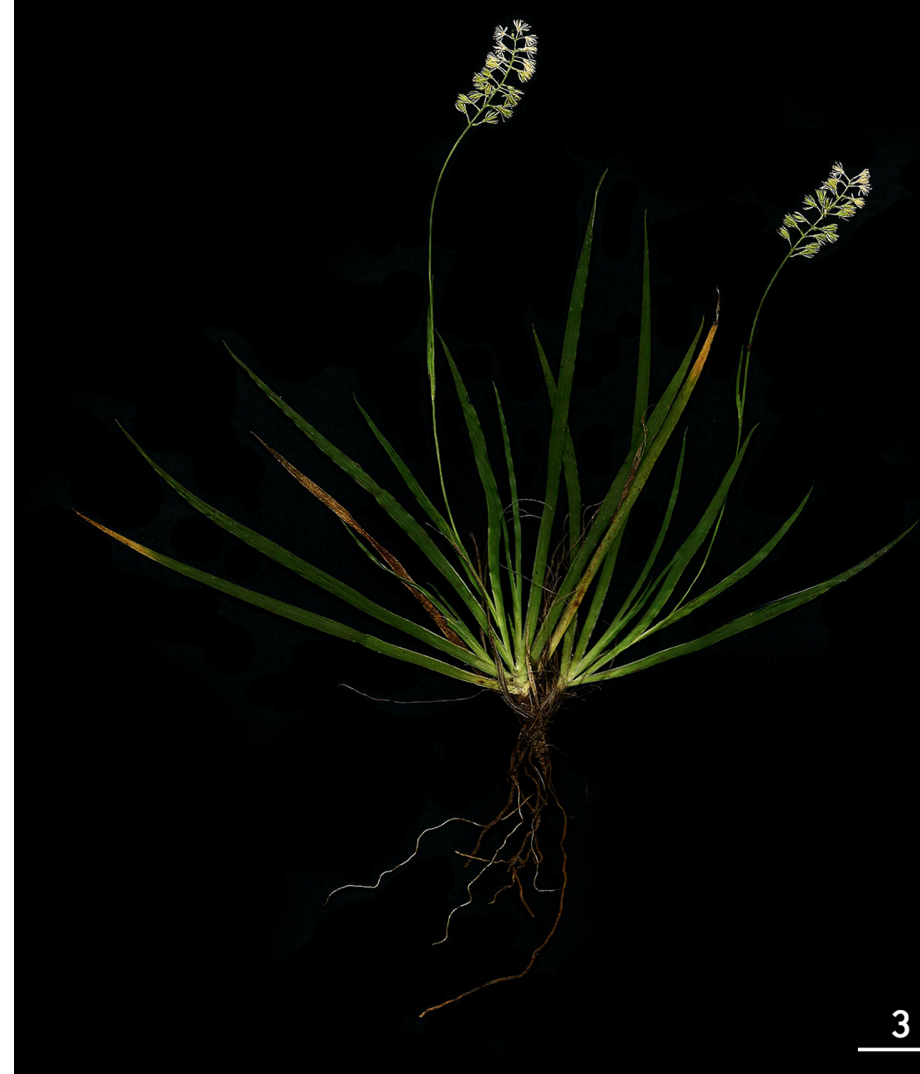

\section{G}

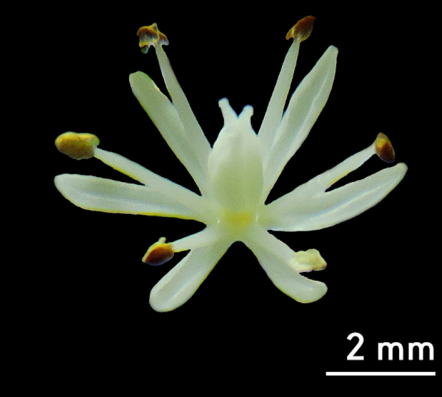

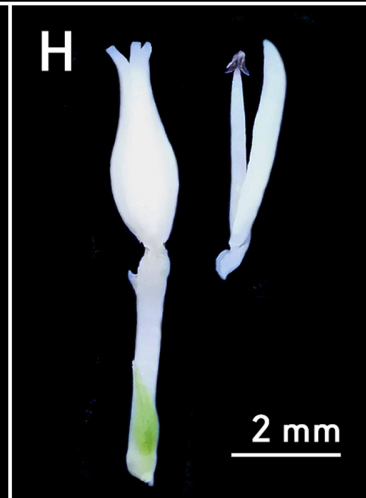

c

D

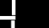


review of relevant literature, we concluded that the collected specimens represent a new taxon in the genus, Tofieldia ulleungensis.

\section{Materials and Methods}

Morphological observations of the new species were conducted based on living plants as well as dry specimens collected between 2018 and 2020. The photographs in the field were captured by using a Nikon Coolpix P510 camera (Tokyo, Japan). The measurements of morphological characters were obtained by using a digital vernier caliper and from data derived from field notes. The flowering and fruiting period is given as cited on the collector's labels. Type material has been deposited in the Korea National Arboretum (KH). The voucher specimens of Korean Tofieldia taxa deposited in the $\mathrm{KH}$ collections were studied.

\section{Taxonomic Treatment}

Tofieldia ulleungensis H. Jo, sp. nov. (Figs. 1, 2).-TYPE:

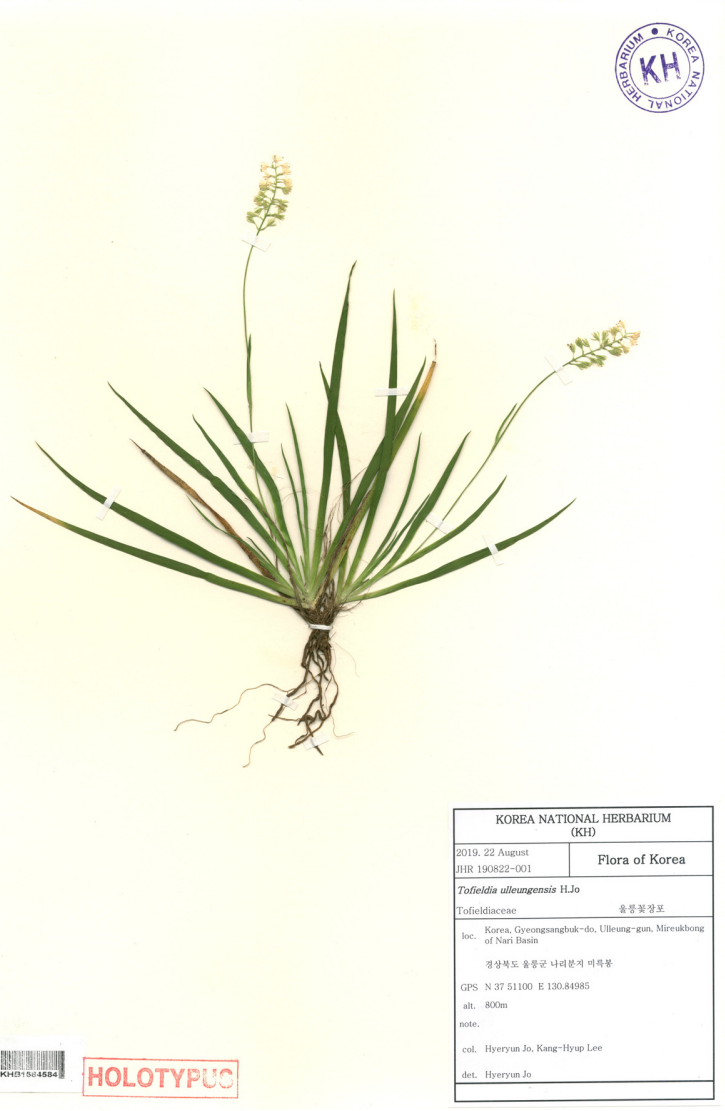

Fig. 3. Holotype of Tofieldia ulleungensis.
KOREA. Gyeongsangbuk-do, Ulleung-gun, Mireukbong of Nari Basin, 3751'10.0"N, 130 $84^{\prime} 98.5^{\prime \prime}$ E, elev. 800 m, 22 Aug. 2019 [fl], JHR 190822-001 [holotype: KH (KHB-1584584), Fig. 3; isotype KH 1 sheet (KHB-1584585), Fig. 4].

Herbs perennial, 10-17 cm tall, with short ascending rhizome. Leaves basal or nearly so, 2-ranked, flattened, 7-15 $\mathrm{cm} \times 5-7 \mathrm{~mm}$, rather rigid, margin scabrous, apex acuminate, 3-5 inconspicuous veins, tip slightly bent. Scape oblique, slender, $12-15 \mathrm{~cm}$ long, with 1 or 2 linear leaves in the proximal part. Racemes ca. $3-5 \mathrm{~cm} \times 8-13 \mathrm{~mm}$, densely manyflowered. Flowers bisexual, arising from axils of bracts, ascending or nearly so; bracts lanceolate; pedicel 2-3 mm long at anthesis; bracteole 1, cupular, apically 2- or 3-lobed. Tepals 6 , white, narrowly oblanceolate-oblong, $3-3.5 \mathrm{~mm} \times$ ca. $0.7-$ $1 \mathrm{~mm}$. Stamens 6 , nearly equaling tepal length; filaments 2.5 $3 \mathrm{~mm}$ long; anthers ca. $0.7 \mathrm{~mm}$ long, light brown to brown. Ovary superior, ca. 1.5-2 mm long, oblong-ovoid, white; styles 3 , revolute, ca. $0.5-0.7 \mathrm{~mm}$ long, nearly as long as anthers; stigma white. Capsule suberect, ca. $4 \mathrm{~mm} \times 3-4 \mathrm{~mm}$, obovoidellipsoid; carpels 2-3.5 $\mathrm{mm} \times 2-2.5 \mathrm{~mm}$, with persistent styles $0.5-1 \mathrm{~mm}$ long and stigmas scarcely thickened. Seeds crescent-

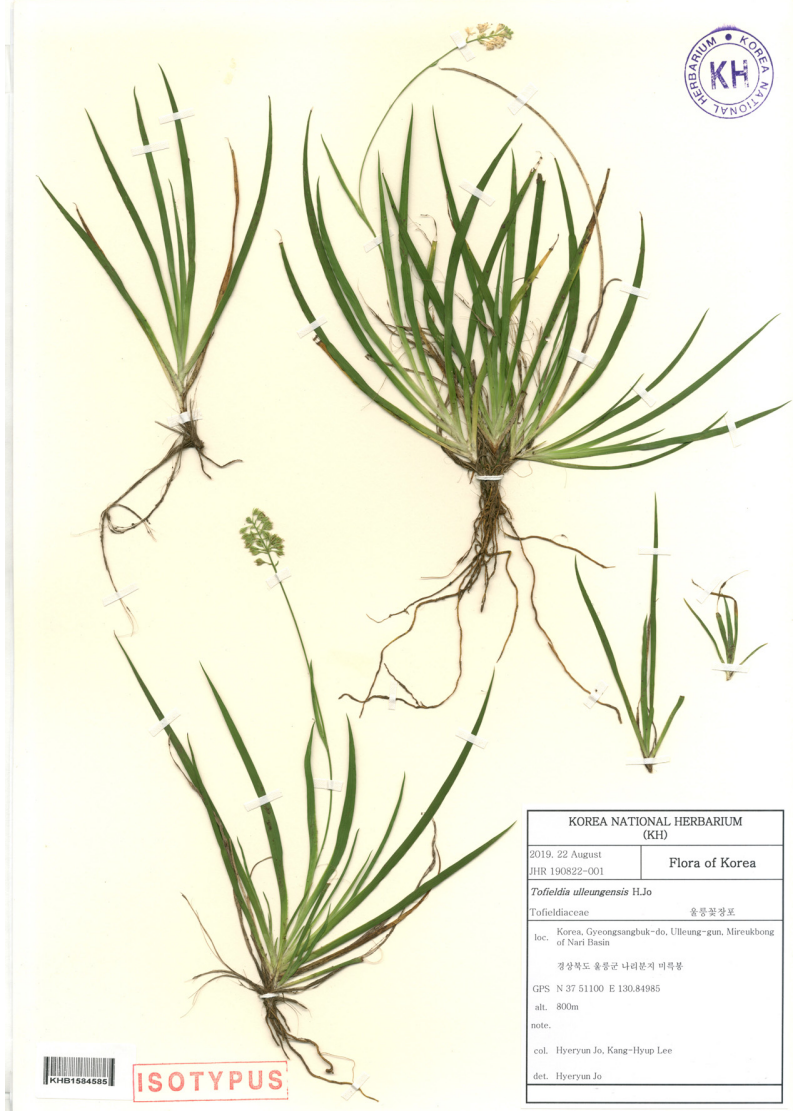

Fig. 4. Isotype of Tofieldia ulleungensis. 


$\begin{array}{cccc}\text { Tofieldia } & \text { T. yoshiiana } & \text { T. coccinea } & \text { T. coccinea } \\ \text { ulleungensis } & \text { var. koreana } & \text { var. coccinea } & \text { var. fauriei }\end{array}$
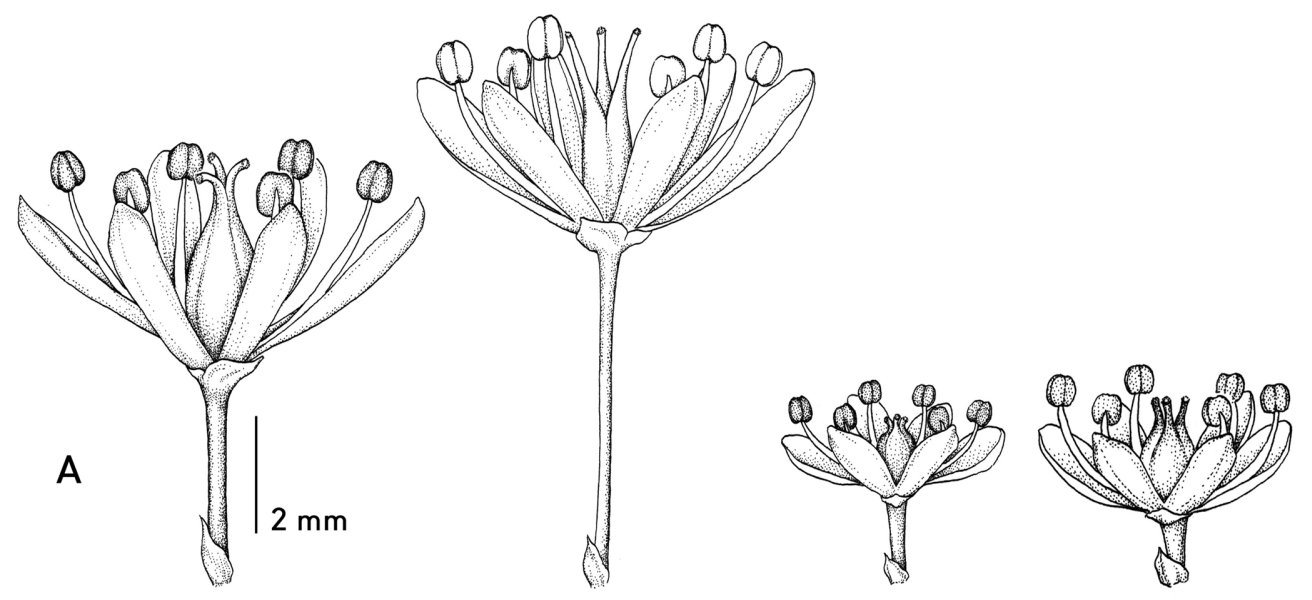

B
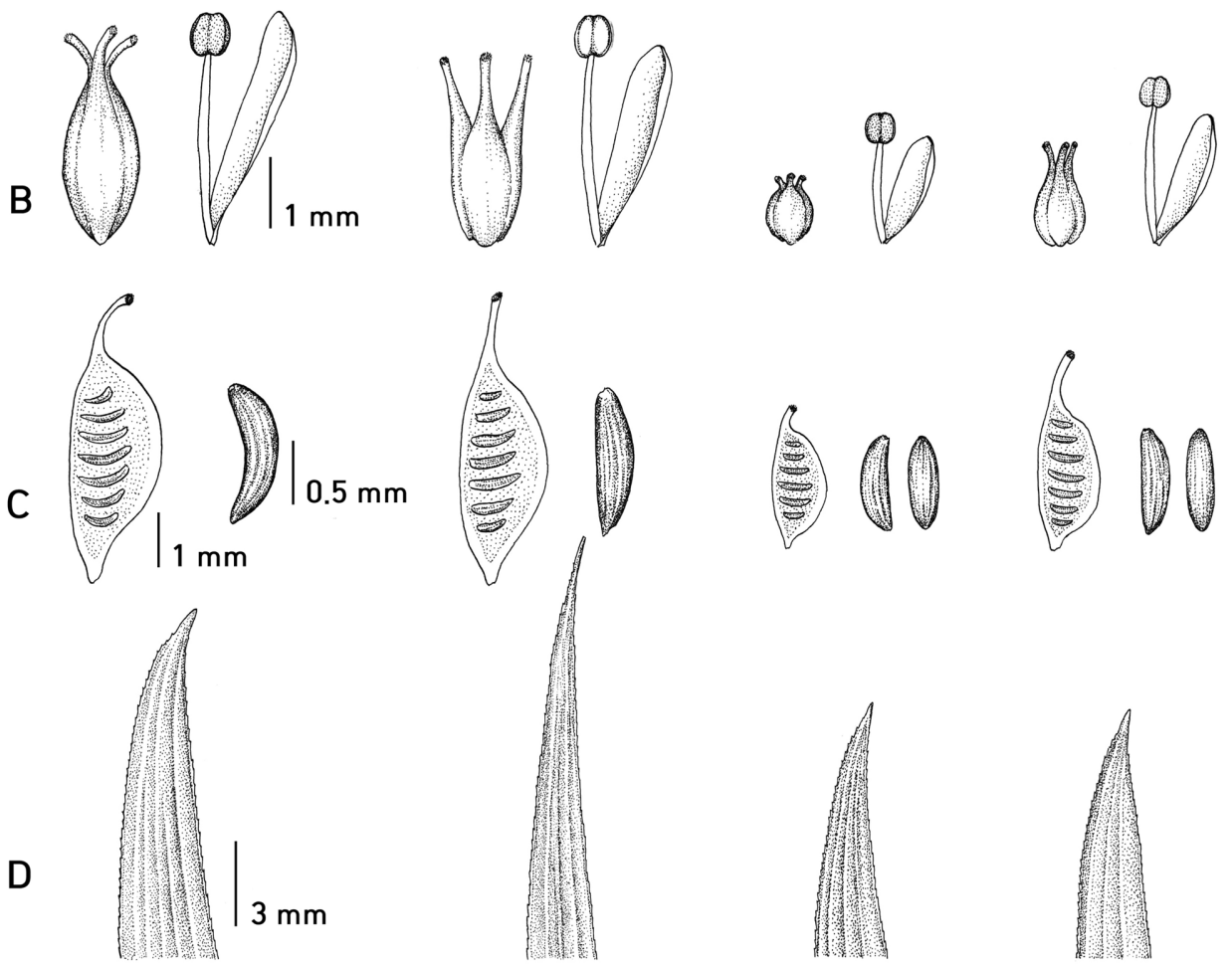

Fig. 5. Comparative illustration of Tofieldia ulleungensis, T. yoshiiana var. koreana, T. coccinea var. coccinea, and T. coccinea var. fauriei. A. Flower. B. Ovary, stamen and tepal. C. Capsule and seeds. D. Leaf apex. Illustrations by Hyeryun Jo.

shaped, ca. $1-1.2 \mathrm{~mm} \times 0.2-0.3 \mathrm{~mm}$, without a white longitudinal band on either side.

Etymology: The specific epithet "ulleungensis" refers to the geographic location Ulleungdo Island, where the species was discovered.

Local name: Ul-leung-kkot-jang-po (울릉꽃장포; new Korean name).

Phenology: Flowering mid-July to late-August.
Distribution and ecology: Republic of Korea, Ulleungdo Island, endemic. Grows in wet rocky areas at high elevations (Fig. 2). Currently, the new species is known only from the type locality and the population is composed of about 50 mature individuals.

Note: Three taxa of Tofieldia (T. yoshiiana var. koreana, T. coccinea var. coccinea, and T. coccinea var. fauriei) have been described in Korea so far. The leaves of $T$. coccinea var. 
Table 1. Comparison of major characters of Tofieldia ulleungensis with related species.

\begin{tabular}{|c|c|c|c|c|c|c|}
\hline \multicolumn{2}{|c|}{ Character } & \multirow{2}{*}{$\frac{\text { T. ulleungensis }}{\text { Absent }}$} & \multirow{2}{*}{$\frac{\text { T. yoshiiana var. yoshiiana }}{\text { Present }}$} & \multirow{2}{*}{$\frac{\text { T. yoshiiana var. koreana }}{\text { Absent }}$} & \multirow{2}{*}{$\frac{\text { T. coccinea var. coccinea }}{\text { Absent }}$} & \multirow{2}{*}{$\frac{\text { T. coccinea var. fauriet }}{\text { Absent }}$} \\
\hline Stolons & & & & & & \\
\hline \multirow[t]{4}{*}{ Leaf } & Length $(\mathrm{cm})$ & $7-15$ & $3.2-13.5$ & $10-14$ & $2.5-5$ & $2.5-5$ \\
\hline & Width (mm) & $5-7$ & - & $1.7-3$ & $2-3$ & $2-4$ \\
\hline & Vein number & $3-5$ & 3 & 3 & 3 & 3 \\
\hline & Margin & Scabrous & Smooth & Scabrous & Scabrous & Smooth \\
\hline \multirow[t]{2}{*}{ Cauline leaf } & Number & $1-2$ & $1-2$ & $3-6$ & $1-2$ & $1-2$ \\
\hline & Length $(\mathrm{cm})$ & $0.5-3$ & - & $0.2-3.5$ & $0.2-2.5$ & $0.5-2.5$ \\
\hline Scape & Length $(\mathrm{cm})$ & $12-15$ & $5.3-18$ & $14-30$ & $5-16$ & $6-21$ \\
\hline \multirow[t]{2}{*}{ Raceme } & Length $(\mathrm{cm})$ & $3-5$ & $1.4-7.8$ & $3-7$ & $0.7-1.5$ & $0.7-1.5$ \\
\hline & Width $(\mathrm{cm})$ & $0.8-1.3$ & $5-22$ & $1.5-2.5$ & $0.6-1.3$ & $0.7-1$ \\
\hline Pedicel & Length (mm) & $2-3$ & $5-25$ & $6-8$ & $1-3$ & $1-3$ \\
\hline \multirow[t]{4}{*}{ Tepals } & Color & White & White or grayish white & White & Purplish white & Purplish white \\
\hline & Length $(\mathrm{mm})$ & $3-3.5$ & - & $2.5-3$ & $1-2$ & $1-2$ \\
\hline & Width (mm) & $0.7-1$ & - & $0.7-1$ & ca. 0.7 & ca. 0.7 \\
\hline & $\begin{array}{l}\text { Ratio of tepal and } \\
\text { stamen }\end{array}$ & Nearly equaling stamen & - & Shorter than stamen & Shorter than stamen & Shorter than stamen \\
\hline Anther & Color & Light brown to brown & Whitish cream & Cream to light yellow & Purple & Brown \\
\hline Ovary & Color & White & White or grayish white & White & Purplish white & Light purple \\
\hline \multirow[t]{2}{*}{ Style } & Shape & Revolute & - & Erect & Revolute & Revolute \\
\hline & Length $(\mathrm{mm})$ & $0.5-0.7$ & $1.5-2$ & $1-1.2$ & $0.3-0.5$ & $0.5-0.7$ \\
\hline Stigma & Color & White & White or grayish white & White & Purple & Purple \\
\hline Seed & Shape & Crescent & - & Linear-semicircular & Linear-semicircular & Linear-semicircular \\
\hline
\end{tabular}

Characters of T. yoshiiana var. yoshiiana are based on the description in the Flora of Japan (Tamura, 2016). 
coccinea and T. coccinea var. fauriei are wide and flattened and style is revolute (Fig. 5). Although, these characters are also common in the new species, the whole plants of $T$. coccinea var. coccinea and T. coccinea var. fauriei can be easily distinguished from the new species by their small size. The tepal and ovary are purplish white in $T$. coccinea var. coccinea and $T$. coccinea var. fauriei but yellowish-white in the new species (Table 1). The new species shows a close morphological similarity with $T$. yoshiiana var. koreana but differs in the morphology of leaves, pedicels, styles, anthers, and seeds. The leaves of $T$. ulleungensis are wide, rigid, and spreading out like a fan, but they are narrow, showing a drooping shape in T. yoshiiana var. koreana. The pedicel is shorter in T. ulleungensis than in T. yoshiiana var. koreana and racemes are cone-like (vs. broad cone in the latter). The styles are revolute and the anthers are light brown to brown in the new species (vs. styles erect and anthers cream to light yellow in $T$. yoshiiana var. koreana). In addition, the seeds are crescentic in $T$. ulleungensis but linear-semicircular in $T$. yoshiiana var. koreana (Fig. 5, Table 1). Meanwhile, the new species differs from $T$. yoshiiana var. yoshiiana which is endemic to Japan by its stolon (vs. absent in T. ulleungensis), smooth leaf margin (vs. scabrous in T. ulleungensis), 5-25 mm long pedicel (vs. 2-3 mm in T. ulleungensis) (Table 1).

\section{Key to Tofieldia ulleungensis and its related taxa in Korea}

1. Leaves shorter than $5 \mathrm{~cm}$; flowers in a dense raceme, raceme length less than $1.5 \mathrm{~cm}$; tepals $1-2 \mathrm{~mm}$ long, purplish white; ovary purplish white; stigma purple $\cdots 2$

1. Leaves longer than $5 \mathrm{~cm}$; flowers in a loose raceme, raceme length more than $3 \mathrm{~cm}$; tepals $2.5-3.5 \mathrm{~mm}$ long, white; ovary white; stigma white ..... 3

2. Leaf margin scabrous; scape oblique; anther purple; ovary orbicular, purplish white

T. coccinea var. coccinea

2. Leaf margin smooth; scape erect; anther brown; ovary ovoid, light purple ………... T. coccinea var. fauriei 3. Leaves narrow, less than $3 \mathrm{~mm}$ wide; pedicel 6 $8 \mathrm{~mm}$ long; stamen obviously longer than tepals, anther cream to light yellow; styles erect; seeds linear-semicircular …… T. yoshiiana var. koreana

3. Leaves wide, more than $5 \mathrm{~mm}$ wide; pedicel $2-3$ mm long; stamen nearly equaling tepals, anther light brown to brown; styles revolute; seeds crescentic

T. ulleungensis

ORCID: Hyeryun JO http://orcid.org/0000-0003-0021-3906;
Balkrishna GHIMIRE https://orcid.org/0000-0002-2169-1280; Young-Ho HA http://orcid.org/0000-0002-2374-3611; KangHyup LEE http://orcid.org/0000-0002-7189-3235; Dong Chan SON http://orcid.org/0000-0002-6773-0580

\section{Acknowledgments}

This study was supported by the Korea National Arboretum, project No. KNA1-2-27, 16-5. We are deeply indebted to Mr. Hyung Ho Yang of Seoul Botanic Park for the kindly provided information. We would like to thank the anonymous reviewers for their valuable comments and suggestions.

\section{Conflict of Interest}

The authors declare that there are no conflicts of interest.

\section{Literature Cited}

Azuma, H. and H. Tobe. 2011. Molecular phylogenetic analyses of Tofieldiaceae (Alistamatales): family circumscription and intergeneric relationships. Journal of Plant Research 124: 349357.

Chen, X. and M. N. Tamura. 2000. Tofieldia Hudson. In Flora of China, Vol. 24. Flagellariaceae through Marantaceae. Wu, Z. Y. and P. H. Raven (eds.), Science Press, Beijing and Missouri Botanical Garden Press, St. Louis, MO. Pp. 76-77.

Chung, T. H. 1957. Korean Flora, Vol. 2. Sinjisa, Seoul, 1025 pp. (in Korean)

Korea National Arboretum. 2017. Checklist of Vascular Plants in Korea. Korea National Arboretum, Pocheon, 1000 pp.

Lee, T. B. 2006. Coloured Flora of Korea, Vol. II. Hyangmunsa, Seoul, 910 pp. (in Korean)

Léviellé, H. 1908. Decades plantarum novarum VIII-X. Repertorium Specierum Novarum Regni Vegetabilis 5: 279-284.

Mabberley, D. J. 2008. Mabberley's Plant Book: A Portable Dictionary of Plants, Their Classification and Uses. 3rd ed. Cambridge University Press, Cambridge, 1040 pp.

Nakai, T. 1911. Flora Koreana, Vol. 2. Journal of the College of Science, Imperial University of Tokyo 31: 1-573.

Nakai, T. 1914. Platae novae Coreanae et Japonicae. I. Repertorium Specierum Novarum Regni Vegetabilis 13: 243-250.

Ohwi, J. 1965. Flora of Japan. Rev. ed. Shibundo, Tokyo, 1560 pp. (in Japanese)

Stevens, P. F. 2001 onwards. Angiosperm phylogeny website, version 9. Retrieved Dec. 28, 2019, available from http:// www.mobot.org/MOBOT/research/APweb/.

Takhtajan, A. 1994. New families of the monocotyledons. Botan- 
icheskii Zhurnal 79: 65-66. (in Russian)

Takhtajan, A. 1997. Diversity and Classification of Flowering Plants. Columbia University Press, New York, 643 pp.

Takhtajan, A. 2009. Flowering Plants. 2nd ed. Springer, Berlin, 968 pp.

Tamura, M. N. 2016. Tofieldia Hudson. In Flora of Japan, Vol. IVb. Angiospermae Monocotyledoneae (b). Iwatsuki, K., D. E. Boufford and H. Ohba (eds.), Kodansha, Tokyo. Pp. 75-79. Tamura, M. N., H. Azuma, J. Yamashita, S. Fuse and T. Ishii. 2010. Biosystematic studies on the family Tofieldiaceae II. Phylogeny of species of Tofieldia and Triantha inferred from plastid and nuclear DNA sequences. Acta Phytotaxonomica et Geobotanica 60: 131-140.

Tamura, M. N., S. Fuse, H. Azuma and M. Hasebe. 2004. Biosystematic studies on the family Tofieldiaceae I. Phylogeny and circumscription of the family inferred from DNA sequences of
matK and $r b c \mathrm{~L}$. Plant Biology 6: 562-567.

Tamura, M. N., S. Fuse, N. S. Lee, O. J. Kim, J. Yamashita and T. Ishii. 2011. Biosystematic studies on the family Tofieldiaceae III. Classification of Tofieldia nuda into three species and three varieties. Taxon 60: 1339-1348.

Tamura, M. N., N. S. Lee, T. Katsuyama and S. Fuse. 2013. Biosystematic studies on the family Tofieldiaceae IV. Taxonomy of Tofieldia coccinea in Japan and Korea including a new variety. Acta Phytotaxonomica et Geobotanica 64: 29-40.

Thorne, R. F. 2000. The classification and geography of the monocotyledon subclasses Alismatidae, Liliidae and Commelinidae. In Plant Systematic for the 21st Century. Nordenstam, B., G. El-Ghazaly and M. Kassas (eds.), Portland Press, London. Pp. 75-124.

Yamazaki, T. 2002. On Tofieldia nuda Maxim. and T. coccinea Richardson. Journal of Japanese Botany 77: 299-303. 